\title{
Pengaruh Laserpunktur dan Penambahan Probiotik dalam Laju Pertumbuhan Sapi Bali (Bos sondaicus) Jantan
}

\section{Effect of Laserpuncture and Addition of Probiotic on Growth Performance Rate in Male Bali Cattle (Bos sondaicus)}

\author{
Febriyono Anggela Prakoso1, Raden Tatang Santanu Adikara ${ }^{2}$, Kusnoto ${ }^{3}$, Sri Hidanah ${ }^{4}$, \\ Yeni Dhamayanti2 ${ }^{2}$ Sunaryo Hadi Warsito ${ }^{4}$ \\ ${ }^{1}$ Mahasiswa, ${ }^{2}$ Departemen Anatomi Veteriner, ${ }^{3}$ Departemen Parasitologi Veteriner, \\ 4Departemen Peternakan, Fakultas Kedokteran Hewan, Universitas Airlangga \\ Corresponding author: febriyono.anggela.prakoso-2015@fkh.unair.ac.id
}

\begin{abstract}
The purpose of this study was to determine the effect of laserpuncture shoot towards the growth rate of male Bali cattle. This reasearch was done in July until August 2018 in Cendono Village, Pasuruan. This research uses 18 samples with completely randomized design as a research methods. This research used 18 male Bali cattle aged $2-2.5$ year. This research divided by 3 groups are the control group (P0, which is without laserpuncture shooting) and two treatment groups (P1, which is laserpuncture shooting with 0.5 joule of doses and P2, which is laserpuncture shooting with 0.5 joule of doses and bioplus probiotic). Laserpuncture shooting already done for 6 weeks with 6 days of interval. The result is weight of cuttle is increasing and it is known from digital weight scales. The data is analyzed by using ANOVA test and followed by Duncan. The result is laserpuncture shooting at the growth point can be increasing the weight of male Bali cattle. Stastical comparison amon P0, P1 and P2 showed there were significant difference on growth rate $(p<0.05)$. The result showed that induction of laserpuncture and bioplus probiotic has effect for growth gain rate of male Bali cattle. The optimal rate of weight gain occured in the second week with laserpuncture induction at dose of 0.5 joule and the six week with laserpuncture induction at dose of 0.5 joule and bioplus probiotic.
\end{abstract}

Keywords: Laserpuncture, male Bali cattle, probiotic Bioplus , growth rate

Received: 08-09-2020 Revised: 09-10-2020 Accepted: 10-11-2020

\section{PENDAHULUAN}

Peranan sapi potong di Indonesia sangat penting. Peran sapi potong adalah sebagai sumber protein hewani, sebagai tabungan yang sewaktu-waktu dapat dijual untuk keperluan tertentu, (Ngadiyono, 2007). Di Indonesia meningkatnya permintaan akan daging sapi dari tahun ke tahun, namun tidak diimbangi dengan peningkatan populasi, sehingga impor sapi ke Indonesia dibuka oleh pemerintah. Permasalahan tersebut sesungguhnya sapi potong masih berpotensi cukup besar untuk dikembangkan.
Permasalahan yang di atas selain teknologi yaitu pengelolaan kandang dari kotoran ternak yang dapat menimbulkan bau tidak sedap yang dapat mendatangkan suatu penyakit sehingga penelitian ini menggunakan teknologi laserpunktur untuk mempercepat laju pertumbuhan berat badan dan pemberian probiotik bioplus untuk membantu laju pertumbuhan berat badan dan menghilangkan bau tidak sedap yang berasal dari feses sapi Bali pada kandang. 
Data Dirjen Peternakan (2008) menyatakan bahwa pada tahun 20062007 menyatakan bahwa kebutuhan nasional daging sapi pada tahun 2006 adalah 395,80 ton. Hal ini juga terjadi pada tahun 2007 yaitu sebanyak 418,20 ton akibatnya terjadi perlambatan produksi daging. Penyediaan daging sapi di Indonesia selama ini sebagian besar bergantung pada usaha penggemukan sapi rakyat yang, sebagaimana diketahui, sistem produksinya masih tradisional dengan hanya mengandalkan potensi hijauan pakan setempat sebagai input untuk proses produksi. Sementara hijauan lokal pada umumnya, Satoto (2004) menyatakan bahwa kandungan nutrisi pada hijauan tersebut relatif rendah karena kurang berdaun dan biasanya dipotong pada umur tua. Hal ini menyebabkan pencapaian yang rendah pada pertambahan bobot badan harian (daily gain) ternak, sehingga waktu yang diperlukan (periode penggemukan) untuk mencapai standar bobot potong menjadi cukup panjang. Akibatnya usaha penggemukan tersebut cenderung kurang efisien dan kenyataannya produksi daging sapi di dalam negeri dan pendapatan peternak menjadi rendah sehingga untuk memenuhi kebutuhan daging dengan jumlah besar, maka diperlukan sistem peternakan yang di dalamnya menggunakan suatu yaitu teknologi laserpunktur.

Konsep laserpunktur merupakan suatu cara pengobatan dan meningkatkan produktivitas yang memanfaatkan titik laserpunktur untuk mempengaruhi aliran bioenergi tubuh berdasar pada filosofi keseimbangan hubungan antara permukaan tubuh dan organ melalui meridian yang spesifik. Adikara (1995) dari hasil penelitian tentang penggunaan laserpunktur untuk penggemukan sapi melaporkan bahwa penembakan sinar laser per minggu pada titik pertumbuhan, ternyata mampu meningkatkan berat badan sapi potong mencapai $7,28 \mathrm{~kg} /$ minggu.

Bagi Peternak ruminansia di Indonesia, dengan pakan berkualitas rendah, sangat dibutuhkan mikroorganisme selulolitik dalam jumlah tinggi agar dapat memanfaatkan hijauan atau limbah pertanian seefisien mungkin dalam menghasilkan gizi yang dibutuhkan oleh ternak (Pamungkas and Anggraeny, 2006). Saat ini banyak dikembangkan probiotik untuk memperbaiki komposisi mikroorganisme yang hidup di bagian usus halus ternak ruminansia untuk meningkatkan produktivitasnya. Probiotik didefinisikan sebagai substrat mikroorganisme, yang diberikan kepada manusia atau ternak lewat pakan dan memberikan efek positif dengan cara memperbaiki keseimbangan mikroorganisme alami di dalam saluran pencernaan. Probiotik berupa Bioplus akan membantu daya cerna ternak terhadap makanan. Bioplus merupakan probiotik yang mengandung isolasi genetik bakteri fermentasi dari genus Lactobacillus acidophilus, Aspergillus oryzae, Saccharomyces cerevisiae, Bacillus subtilis, Rhodopseudomonas sp, Actinomycetes, dan Nitrobacter dalam media molases untuk memfermentasikan bahan organik kompleks menjadi bahan organik sederhana (Herry, 1996). Pemberian bioplus cair sebanyak 5 cc per ekor per hari pada sapi PO dengan pakan berupa rumput $10 \%$ dan konsentrat $1 \%$ dari berat badan memberikan peningkatan berat badan rata-rata $0,9 \mathrm{~kg} /$ ekor/hari Sedangkan kombinasi bioplus dengan laserpuntur dengan pemberian pakan seperti di atas memberikan peningkatan berat badan antara 1,2 $-1,3$ kg/ekor/hari (Herry, 1996).

Berdasarkan pertimbangan di atas, maka perlu dilakukannya penelitian ini untuk mengetahui pengaruh penembakan laserpunktur 
serta pemberian probiotik bioplus terhadap laju pertumbuhan sapi Bali yang diamati selama 36 hari.

\section{METODE}

\section{Waktu dan tempat penelitian}

Penelitian ini dilaksanakan selama enam minggu pada bulan Juli sampai Agustus 2018, yang dilakukan di Desa Cendono Kecamatan Purwosari Kabupaten Pasuruan, Jawa Timur.

\section{Bahan dan alat penelitian}

Hewan coba yang digunakan dalam penelitian ini adalah sapi Bali jantan sejumlah 18 ekor dalam keadaan sehat. Pakan yang digunakan adalah konsentrat, rumput gajah, ampas singkong, ampas tahu dan jerami padi. Kandang yang digunakan dalam penelitian ini yaitu kandang individu model dua baris sebagai tempat pemeliharaan sapi dan kandang jepit untuk perlakuan. Kandang jepit dengan ukuran panjang $110 \mathrm{~cm}$, lebar $70 \mathrm{~cm}$, tinggi $110 \mathrm{~cm}$ kemudian disekat dengan pagar tralis untuk tiga perlakuan .

Alat yang dibutuhkan untuk penelitian ini antara lain seperangkat laserpunktur semikonduktor dengan power supply 20-100 mW, kandang, timbangan serta alat kebersihan.

\section{Perlakuan}

Sapi Bali jantan yang diperlukan untuk penelitian ini adalah sapi Bali yang telah berumur 2-2,5 tahun yang sudah dewasa, dipilih secara acak, serta kondisi sehat. Sapi yang sudah terpilih diberikan makanan setelah dan sudah diberikan probiotik Bioplus dengan cara dicontangkan ke arah mulut sapi Bali dengan spuit $5 \mathrm{ml}$ kemudian mempersiapkan timbangan dan kandang jepit untuk dilakukan terapi laserpunktur dilakukan seminggu sekali dan pemberian probiotik Bioplus sehari sekali yang sesuai dengan perlakuan.
Sapi Bali dimasukkan ke dalam kandang jepit kemudian ditenangkan Selanjutnya dilakukan penembakan laserpunktur pada titik pertumbuhan yaitu titik paru-paru (terletak antara os costae 6-7-8-9-10 bagian dorsal, sepanjang $\mathrm{m}$. longisimus dorsi sebelah ventral). Rangsangan pada titik ini dapat meningkatkan konsumsi oksigen. titik jantung (terletak di daerah pertengahan os humerus pada intercostae 5-6 di daerah pertengahan os costae). Rangsangan pada titik ini akan meningkatkan aliran darah keseluruh tubuh, titik lambung (terletak di daerah dorsal diantara os costae 1011-12-13 di sepanjang wilayah ventral $\mathrm{m}$. longisimus dorsi). Rangsangan pada titik ini akan meningkatkan daya cerna dan daya serap organ pencernaan (Adikara, 1995).

Setelah menemukan letak titik dengan benar, lalu dilakukan penembakan dengan sinar laser $0,5 \mathrm{~J}$ pada kelompok P1 dan 0,5 J dan bioplus pada kelompok perlakuan P2. Sedangkan kelompok PO dilakukan penembakan tetapi alat laserpunktur dimatikan dayanya sehingga tingkat stres antara sapi perlakuan dan kontrol sama. Penembakan dilakukan pada sapi dengan interval waktu penembakan enam hari sekali.

Percobaan dilakukan dengan tiga perlakuan dan enam pengulangan. Perlakuan yang diteliti yaitu: (PO) Sapi tanpa perlakuan laserpunktur maupun tanpa pemberian bioplus (sebagai kontrol); (P1) Sapi mendapat perlakuan laserpuntur dengan dosis 0,5 Joule setiap minggu; (P2) Sapi diberikan bioplus $5 \mathrm{cc} /$ ekor/hari ditambah dengan perlakuan laserpuntur dengan dosis 0,5 Joule setiap minggu.

\section{Analisis data}

Analisis data dengan software spss versi 25. Uji tingkat perbedaan respon antar perlakuan dianalisis 
menggunakan ANOVA dilanjutkan dengan uji Duncan.

\section{HASIL DAN PEMBAHASAN}

Data yang didapatkan diuji menggunakan ANOVA (Analysis of Varience) dan dilanjutkan dengan uji Duncan yang kemudian menunjukkan angka rata-rata dan standar deviasi (simpangan baku) dapat dilihat pada Tabel 1.

Tabel 1. Mean dan Standar deviasi (SD) laju pertumbuhan sapi Bali jantan umur 2-2,5 tahun selama 6 minggu.

\begin{tabular}{cccc}
\hline \multirow{2}{*}{ Amatan } & \multicolumn{3}{c}{$\begin{array}{c}\text { Pertambahan Berat } \\
\text { Badan (kg) }\end{array}$} \\
\cline { 2 - 4 } & P0 & P1 & P2 \\
\hline Minggu & $3,17^{\mathrm{a}}$ & $8,67^{\mathrm{b}}$ & $18,83^{\mathrm{c}}$ \\
1 & $\pm 0,75$ & $\pm 1,63$ & $\pm 2,14$ \\
Minggu & $3,17^{\mathrm{a}}$ & $10,33^{\mathrm{b}}$ & $17,33^{\mathrm{c}}$ \\
2 & $\pm 1,47$ & $\pm 2,07$ & $\pm 1,51$ \\
Minggu & $2,67^{\mathrm{a}}$ & $7,17^{\mathrm{b}}$ & $17,83^{\mathrm{c}}$ \\
3 & $\pm 1,03$ & $\pm 1,60$ & $\pm 1,47$ \\
Minggu & $3,33^{\mathrm{a}}$ & $8,00^{\mathrm{b}}$ & $18,67^{\mathrm{c}}$ \\
4 & $\pm 0,82$ & $\pm 0,89$ & $\pm 1,03$ \\
Minggu & $2,33^{\mathrm{a}}$ & $8,67 \mathrm{~b}$ & $18,50^{\mathrm{c}}$ \\
5 & $\pm 0,82$ & $\pm 1,37$ & $\pm 0,55$ \\
Minggu & $3,00^{\mathrm{a}}$ & $8,00^{\mathrm{b}}$ & $19,00^{\mathrm{c}}$ \\
6 & $\pm 0,89$ & $\pm 0,63$ & $\pm 0,63$ \\
\hline
\end{tabular}

Pada tabel di atas menunjukkan bahwa hasil rerata dan standar deviasi (SD) laju pertumbuhan sapi Bali jantan setelah penembakan laserpunktur pada titik pertumbuhan selama enam minggu dengan interval waktu enam hari yang menunjukkan perbedaan nyata dengan P0 adalah P2 dan P1 ( $<<0,05)$. Hal ini menunjukkan bahwa penembakan laserpunktur P1 dengan dosis 0,5 Joule dan P2 dengan dosis 0,5 Joule dan penambahan probiotik Bioplus dapat meningkatkan laju pertambahan.

Laju pertumbuhan berat badan selama enam minggu setelah dilakukan penembakan laserpunktur dan pemberian probiotik Bioplus mengalami perbedaan yang nyata antara lain sapi yang di tembakkan laser tanpa pemberian probiotik Bioplus dengan sapi yang di tembakkan laser dengan pemberian probiotik bioplus. Pada hasil penelitian ini secara nyata pertambahan berat badan P2 akan lebih tinggi secara signifikan terhadap P1.

Kisaran laju pertumbuhan berat badan selama enam minggu tersebut pada $\mathrm{P} 1$ antara $7,17 \pm 1,60 \mathrm{~kg}$ sampai $10,33 \pm 2,07 \mathrm{~kg}$, sedangkan pada laju pertumbuhan P2 antara $17,33 \pm 1,51 \mathrm{~kg}$ sampai $18,67 \pm 1,03 \mathrm{~kg}$, untuk $\mathrm{PO}$ berada pada kisaran angka 2,33 $\pm 0,82$ $\mathrm{kg}$ sampai 3,00 $\pm 0,89 \mathrm{~kg}$.

Berdasarkan hasil grafik juga menunjukkan semua perlakuan saling berbeda nyata. Dengan ururtan dari yang terbaik dimulai dari P2, P1, dan PO.

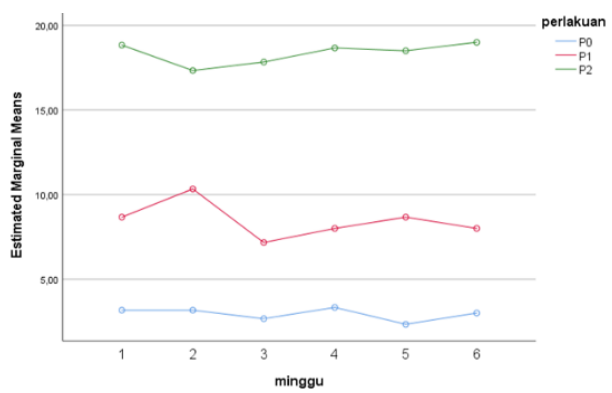

Gambar 1. Grafik laju pertumbuhan sapi Bali jantan selama 6 minggu.

Laju pertumbuhan adalah ukuran yang berdasarkan pada pertambahan berat badan per satuan waktu. Pertumbuhan tidak hanya pertambahan berat, tetapi dapat meliputi perubahan komponen-komponen kimia yaitu air, protein dan abu mineral. Laju pertumbuhan yang berhasil akan dicapai bila kondisi lingkungan sangat menunjang (Adiwinarto, 2005). Laju pertumbuhan dihitung berdasarkan selisih berat badan sapi Bali tiap minggunya. Laju pertumbuhan berdasarkan diagram yaitu titik infleksi terjadi pada minggu keenam pada perlakuan P2. Pada titik infleksi ini, titik yang mencapai pertumbuhan maksimum. Tulang tumbuh secara kontinyu dengan laju pertumbuhan yang relatif lambat sedangkan 
pertumbuhan otot relatif lebih cepat, sehingga rasio antara otot dan tulang meningkat selama pertumbuhan (Parakkasi, 1999). Otot mencapai pertumbuhan maksimal kemudian terjadi pertambahan bobot otot terutama karena deposisi lemak intra muscular (Soeparno, 2005).

Laserpunktur pada titik pertumbuhan mampu meningkatkan pertambahan berat badan. Hal ini disebabkan karena perlakuan laserpunktur pada mekanisme dari laserpunktur yaitu memberikan rangsangan pada titik akupunktur yang terletak pada jalur meredian. Rangsangan tersebut dapat menimbulkan aliran bioenergi untuk keseimbangan tubuh (Oetomo, 1980). Penembakan laserpunktur juga dapat meningkatkan kapasitas dan efesiensi dalam metabolisme tubuh sehingga mampu meningkatkan prestasi biologisnya, seperti kerja hormonal dan reaksi biokimiawi (Adikara, 1995). Hormon pertumbuhan sangat diperlukan untuk pertumbuhan dan metabolisme karbohidrat, lemak dan mineral (Parakkasi, 1999).

Penembakan laserpunktur pada titik paru-paru, titik jantung, dan titik lambung yang berawal dapat meningkatkan kemampuan paru-paru dalam menyediakan oksigen selanjutnya untuk kebutuhan oksigen di dalam jantung dapat meningkatkan cardiac output (Adikara, 1994). Guyton dan hall (2007) menyatakan bahwa peningkatan cardiac output disebabkan oleh meningkatnya konsumsi oksigen dari jaringan sehingga kapasitas organ kerja jantung lebih besar dan akan meningkatkan metabolisme dan memperlancar peredaran darah tubuh, memacu jantung untuk mendistribusikan zat-zat makanan (Adikara 1994). Rangsangan pada lambung akan meningkatkan kerja enzim pencernaan sehingga efektivitas pencernaan meningkat untuk menstimulasikan organ tersebut yang berjarak sekitar kurang lebih $5 \mathrm{~cm}$ dari permukaan kulit (Dharmawan, 2017). Secara mekanisme penembakan laser melalui titik akupunktur yaitu dimulai dari sinar laser atau radiasi ditembakkan pada titik akupunktur akan memberikan respon munculnya energi yang selanjutnya dialirkan pada jalur meredianya, energi tersebut akan melintasi titik akupunktur berikutnya dalam satu jalur meredian, yang akhirnya menuju ketarget organ. Perjalanan energi terjadi dari titik akupunktur menuju ke target organ. Organ yang terkait akan merespon energi yang diterimanya dan akan terjadi perubahan-perubahan fisiologi dan biokimia, seperti peningkatan kerja dan kapasitas organ, terbentuknya enzim atau hormonal. Titik yang ditembakkan tersebut berhubungan dengan rangsangan untuk meningkatkan kerja organ. Perubahanperubahan fisiologi dan biokimia (perubahan sintesa enzim dan hormonal, perubahan kinerja organ tergantung dosis laser yang diberikan dan tambahan lain yang membantu untuk mempercepat pertumbuhan). Hal ini diperkuat oleh penelitian Adikara (1994), menyatakan bahwa fase awal rangsangan titik akupuntur, dapat memberikan perubahan listrik dan ion yang ada didaerah tersebut. Diduga selsel yang terdapat pada titik-titik akupuntur mempunyai kepekaan terhadap rangsangan dan menimbulkan pesan pesan molekular (kimiawi) dan merambat melalui sistem seluler menuju target organ. Pesan-pesan dari molekuler ini bisa masuk kedalam sel dan mempengaruhi sintesa protein dari sel, sehingga dapat membentuk suatu enzim atau substrat yang dapat meningkatkan efisiensi dan produktifitas jaringan tubuh atau organ sehingga dapat berdampak pada peningkatan laju pertumbuhan. 
Pada penelitian ini hasil laju pertumbuhan berat badan sapi Bali selama penggemukan yang tertinggi terjadi pada Sapi Bali yang diberikan dosis 0,5 Joule dan pemberian probiotik Bioplus (P2) pada minggu ke-1. Budiarsana (1997) menyatakan bahwa pada minggu pertama bobot badan sapi penggemukan meningkat sangat tinggi. Peningkatan berat badan sapi yang tinggi pada awal penggemukan tersebut diduga disebabkan oleh kebutuhan protein dapat dimetabolisme lebih banyak karena berkaitan dengan pertumbuhan otot yang sangat cepat. Pada minggu kedua pada P2 laju pertumbuhan berat badan menurun dikarenakan kemungkinan kondisi ternak mulai menyesuaikan keadaan lingkungan yang nyaman dari lingkungaan sebelumnya dan pada minggu lanjutnya kenaikan berat badan mengalami kestabilan.

Konsumsi protein dan energi yang lebih tinggi akan menghasilkan laju pertumbuhan yang cepat (Wahyono, 2002). Pada perlakuan P2 yang paling tinggi dibandingkan dengan P1 karena terdapat dua terget pada P2 yaitu perlakuan dari laserpunktur menargetkan pada ternak dan probiotik Bioplus menargetkan pada pakan. Penambahan probiotik Bioplus pada pakan menjadi salah satu solusi untuk menangani masalah pertambahan berat badan karena penambahan. Probiotik Bioplus memberikan fermentasi didalam rumen untuk membantu memecahkan protein dan serat kasar dalam rumen oleh mikroba sehingga mudah diserap tubuh di dalam usus halus (Herry, 1996).

Probiotik Bioplus ini mengandung berbagai macam mikroorganisme bakteri dan jamur, seperti: Lactobacillus acidophilus, Aspergillus oryzae, Saccharomyces cerevisiae, Candida pintolopesii dan Bacillus subtilis. Saccharomyces cerevisiea dan Aspergillus oryzae merupakan jenis fungi yang banyak digunakan dalam pakan ternak. Saccharomyces cerevisiea mempunyai karakteristik khusus dalam pakan ternak karena kemampuannya memproduksi asam glutamat yang dapat meningkatkan palatability dari pakan tersebut. Aspergillus oryzae dapat mengeluarkan beberapa enzim seperti amilase, protease, aminoglukosidase dan selulase. Enzimenzim tersebut dapat meningkatkan kecernaan pakan dan mempercepat proses pencernaan (Pamungkas dan Anggraeny, 2006). Bacillus subtilis yang berperan pada meningkatkan nilai kecernaan pakan sapi pedaging selain itu bakteri tersebut dapat mengendalikan pathogen jamur dan bakteri berbahaya (Pamungkas dan Anggraeny, 2006). Rhodopseudomonas sp merupakan mikroba pengurai dimana didalamnya terkandung bakteri fotosintetik (Kukuh, 2010). Actinomycetes berperan menghasilkan zat anti yang dapat menekan pertumbuhan bakteri pathogen (Kukuh, 2010). Nitrobacter adalah untuk Mengurai Amoniak penyebab bau busuk pada kandang yang disebabkan oleh sisa pakan dan feses atau kotoran ternak (Kukuh, 2010).

\section{KESIMPULAN}

Berdasarkan penelitian dan pembahasan hasil yang dilakukan, dapat disimpulkan bahwa penembakan laserpunktur dengan dosis 0,5 Joule pada titik pertumbuhan sapi Bali dapat berpengaruh terhadap laju pertumbuhan sapi Bali jantan dan perlakuan penembakan laserpunktur dengan dosis 0,5 Joule pada titik pertumbuhan sapi Bali dan penambahan probiotik Bioplus dapat berpengaruh laju pertumbuhan sapi Bali jantan.

\section{DAFTAR PUSTAKA}


Adikara, R.T.S. 1994. Aplikasi Teknologi Akupunktur untuk Bioteknologi Peternakan dalam Usaha Peningkatan Pertumbuhan Ternak Sapi Potong, indonesian Journal of Acupuncture (Meridian), 2(2): 16-24.

Adikara, R.T.S. 1995. Fisiologi Kesimbangan (Taoisme) dalam Era Iptek Modern Utama Pembangunan Bangsa Indonesia. Meridian I(I): 118122.

Adiwinarto, Gatot. 2005. Penampilan dan Laju Pertumbuhan Relatif Karkas dan Komponen Karkas Dua Strain Ayam Broiler Fase Finisher dalam Berbagai Suhu Penelitian [Thesis]. Program Studi Magister Ilmu Ternak. Fakultas Peternakan. Universitas Diponegoro. Semarang.

Budiarsana, I.G.M., dan B. Haryanto. 1997. Analisis Ekonomi Penggemukan Sapi PO dengan Pemberian Pakan Mengandung ByPassprotein. Prosiding Semiinar Nasuonal Peternakan dan Veterinar, Bogor 18-19 Nopember 1997, Jilid II. Puslitbang Peternakan, Bogor: 749757.

Dharmawan, N. S. 2017. Pengantar Ilmu Kedokteran Hewan Tradisional. Fakultas Kedokteran Hewan. Universitas Udayana. Denpasar. 4749.

Direktorat Jenderal Peternakan. 2008. Petunjuk Teknis Pembibitan Ternak Rakyak (Village Breeding Centre atau VBC). Ditjen Peternakan, Jakarta.

Guyton, C.A. \& Hall, E.J. 2007. Buku Ajar Fisiologi Kedokteran; alih bahasa, Irawati, et.al; editor edisi bahasa Indonesia, Luqman Yanuar Rahman. Edisi 11. Jakarta: EGC.
Herry A.H., 1996. Teknologi Bioplus untuk Hewan Ternak. Fakultas Kedokteran Hewan Universitas Airlangga, Surabaya.

Kukuh. R. 2010. Pengaruh Suplementasi Probiotik Cair EM4 terhadap Performan Domba Lokal Jantan.

Fakultas Pertanian, Universitas Sebelas Maret, Surakarta. Hal 29 Ngadiyono, N. 2007. Beternak Sapi. PT Citra Aji Pratama, Yogyakarta.

Oetomo. 1980. Seni Akupunktur Modern. Bharata. Jakarta. 1-9.

Pamungkas, D dan Anggraeny, NY. 2006. Probiotik Dalam Pakan Ternak Ruminansia. vol. 16. no. 2.

Parakkasi, A. 1999. Ilmu Nutrisi dan Makanan Ternak Ruminan. Cetakan Pertama Penerbit UP. Jakarta.

Satoto. B. 2004. Pakan Ternak Potong. Dalam: Pedoman Teknis Pengembangan Usaha Ternak Potong. Pribadi, L.W. (Ed.). IKP Unpad, Bandung.

Soeparno, 2005. Ilmu Tekhnologi Daging. Gajah Mada University Press, Yogyakarta.

Wahyono, F. 2002. Pengaruh Teknologi Probiotik Terhadap Tingkat Konsumsi Pakan, Pertumbuhan Bobot Badan dan Kolesterol Darah Ayam Broiler yang Diberi Pakan Tinggi Lemak Jenuh dan Lemak Tak Jenuh. J. Pengembangan Peternak Tropis. 27:36-43. 